\title{
The concept of lichen refugia classification. A proposal based on the case study of Krajeńskie Lakeland, Poland
}

\author{
Wojciech Gruszka \\ Department of Biology, Morphological and Health Sciences, Faculty of Physical Culture in Gorzów Wlkp., \\ University School of Physical Education in Poznań, Estkowskiego 13, \\ 66-400 Gorzów Wlkp., Poland, e-mail: elm1@interia.pl
}

Received: 17 August 2017 / Accepted: 02 October 2017

\begin{abstract}
The article presents a proposal for the classification of lichen refuges based on the research conducted in the Krajeńskie Lakeland in 2009-2014. Four types of refuges have been distinguished during the research: 1 - primeval (natural) - associated with the least transformed areas, 2 - regenerative (semi-natural) - with species of high conservation value, spread by natural forces despite a small anthropogenic impact, 3 - colonized (anthropogenic) - solely formed by human activity and extraneously inhabited by adventive lichens, 4 - incidental (spontaneous) - formed instantaneously as a result of a favourable situation or an event. The last type was not found in the course of the study. The publication presents the characteristics of all types of refuges along with a key for their identification.
\end{abstract}

Key words: lichens, refuge, endangered species, Krajeńskie Lakeland.

\section{Introduction}

Refuge (lat. refuge from refugere - escape, avoid, escape alive) (Kopaliński, 2007), according to IPA (Important Plants Areas) (including also bryophytes, macrophytic algae, macromycetes fungi, lichens and mycetozoa) is defined as: "a natural or semi-natural area, distinguished by exceptional botanical richness and/or constituting the habitat for the distinctive set of rare, threatened and/or endemic plant species and/or plant communities of high botanical value" (Mirek et al., 2005).

Refuges play an increasingly important role in preserving and sustaining biodiversity in the landscape transformed by man. It is particularly important for endangered, rare or relict species, which are a remnant of the previous ecological systems. Selecting and protecting areas with refuge characteristics may increase the chances of regional survival of the most valuable species.
However, in the lichenological literature, the issue of lichen refuges is a main research subject in only few publications (Cieśliński, 1999, 2000, 2006; Kossowska, 2002; Kościelniak, 2005, 2009; Wójciak \& Urban, 2012; Kapek, 2014). In most of them, the issue of refuges appears in study summaries and/or has only additional aspect (Cieśliński, 2003; Kukwa \& Jabłońska, 2006; Kolanko, 2009; Gruszka, 2010, 2011; Kubiak, 2011; Bielczyk, 2012; Czarnota, 2012; Hachułka, 2012; Kubiak \& Sucharzewska, 2012; Golubkov et al., 2012; Kościelniak, 2012).

Given the scarcity of scientific publications on this topic, the intention of this study was to propose the author's attempts to classify lichen refuges and initiate an evidence-based discussion. 


\section{Study area}

The mesoregion of the Krajeńskie Lakeland is located in north-western Poland (Fig. 1). It belongs to the North European Plain Province, Southern Baltic Lakelands Subprovince and the region of Southern Pomerania Lakeland. It is located between the Gwda Valley, Brda Valley and Central Noteć Valley, surrounded by Charzykowska Plain and Tuchola Forest in the north. It occupies an area of approximately $4380 \mathrm{~km}^{2}$ (Kondracki, 2001). Krajeńskie Lakeland is located between $53^{\circ} 05^{\prime}$ and $53^{\circ} 50^{\prime}$ ' north latitude and between $16^{\circ} 45^{\prime}$ and $17^{\circ} 50^{\prime}$ east longitude (Umiński, 1991).

Krajeńskie Lakeland is a typical agricultural land (more than $70 \%$ of the area) (Waldon \& Ratyńska, 2008), its forest cover is $27.3 \%$ (Trampler et al., 1990). The dominant forest associations are pine forests and mixed forests, although there are also large associations of mixed deciduous forests. The stands mainly consist of Pinus sylvestris (over 85\%), the undergrowth is dominated by Juniperus communis, Frangula alnus and Corylus avellana as well as Quercus spp., Fagus sylvatica and Acer spp. saplings (Umiński, 1991). Forests in the vast majority are very homogeneous. The vast majority of forest area is occupied by single-storied stands. The decisive factor in recent years was the promotion of single-species plantings (Prognoza oddziaływania..., 2005).

\section{Methods}

Field study of the mesoregion was conducted in the years 2009-2014. Studies involving marking areas as refuges require examining the terrain of reference, in order to select especially valuable species, which are indicators of the refuge. Therefore, the material collection sites were selected in such a way so to obtain a comprehensive information of the lichen biota in the entire area. The obtained results are a model for the analysis of distribution diversity of lichen biota, and thus a reference point indicating the most valuable areas.

The specimens of common species, easy to identify in the field, were not collected and only their presence was recorded. Lichen specimens were collected to identify them in the laboratory. Thin layer chromatography (TLC) was used in determining the types of secondary metabolites in sterile crustose lichens (for example genus Lepraria or Chrysothrix flavovirens) according to the guidelines of Orange et al. (2001) and Kubiak and Kukwa (2011). All the collected and marked specimens were placed in the herbarium of the Department of Biology, Morphological and Health Sciences, Faculty of Physical Culture in Gorzów Wielkopolski. The nomenclature follows Index Fungorum (date of exploration 26.09.2017)

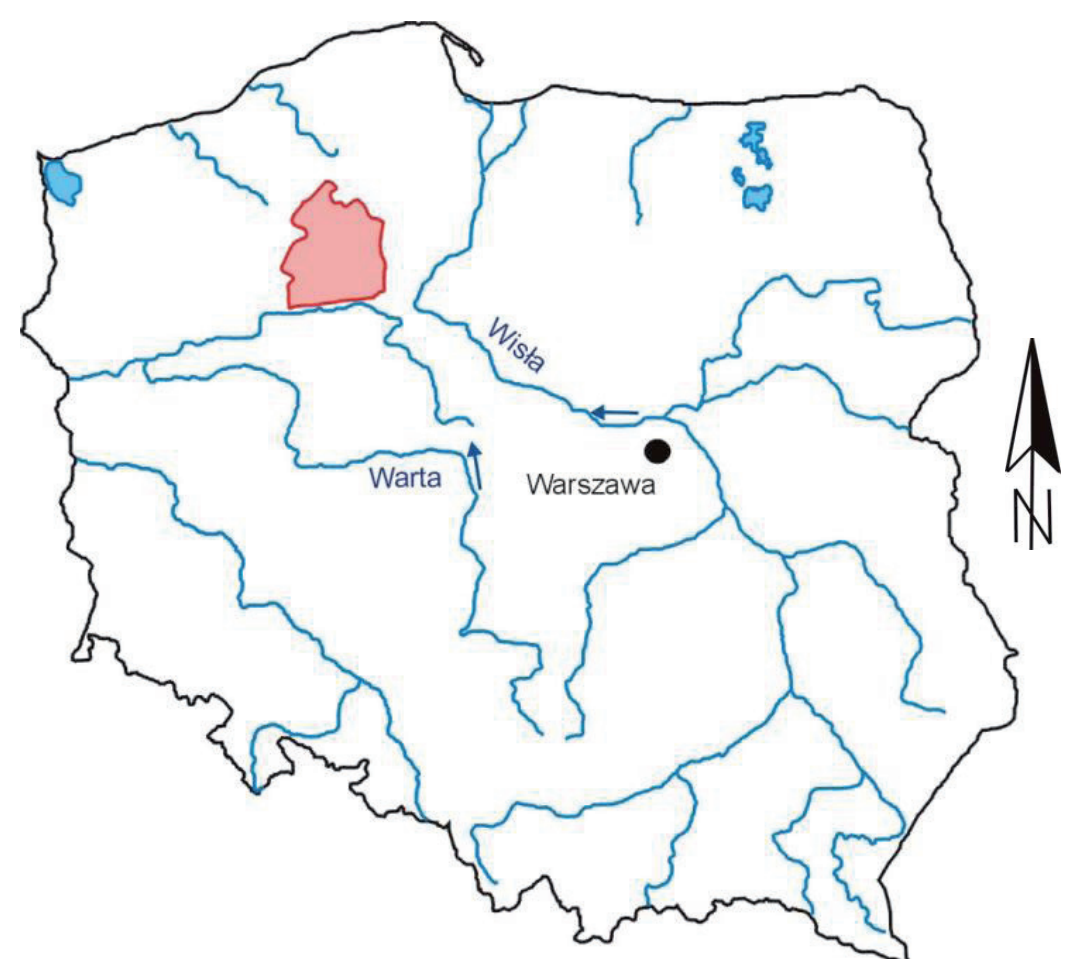

Figure 1. Location of the Krajeńskie Lakeland in Poland (Gruszka, 2014) 


\section{Results}

In total, 160 species of epiphytic lichens have been identified in the Krajeńskie Lakeland, as a result of the present research (Gruszka, 2014). Among the identified taxa 34 are new to the area, 69 are included in the Red list of species threatened with extinction in Poland by Cieśliński et al. (2006). The largest group are the endangered species (23 species) and vulnerable (22 species), the smallest represented only by two least concern taxa. 11 species are under partial protection and 18 are under strict pro- tection (Rozporządzenie, 2014). Of all identified species of lichens, the most valuable 43 species were identified as indicators of refuges (Table 1). Most of them belong to endangers of extinction in the country and they are rare (or very rare) on Krajeńskie Lakeland. 9 areas were marked as lichen refuge in Krajeńskie Lakeland. Among the identified six were located in the existing nature reserves.

\subsection{Classification of refuges}

On the basis of the comparative analysis of the characteristics of each refuge (including, the degree of naturalness,

Table 1. Species that distinguish forest areas as refuges of lichens in the Krajeńskie Lakeland

\begin{tabular}{|c|c|c|}
\hline Species & Primeval refuge & Regenerative refuge \\
\hline $\begin{array}{l}\text { Acrocordia gemmata } \\
\text { (Ach.) A. Massal. }\end{array}$ & + & \\
\hline Alyxoria varia (Pers.) Ertz \& Tehler & + & + \\
\hline Arthonia atra (Pers.) A. Schneid. & + & + \\
\hline Arthonia spadicea Leight. & + & \\
\hline Arthonia vinosa Leight. & + & \\
\hline Arthothelium ruanum (A. Massal.) Körb. & + & \\
\hline Bacidia arceutina (Ach.) Arnold & + & \\
\hline Bacidia circumspecta (Norrl. \& Nyl.) Malme & + & \\
\hline Bacidia rosella (Pers.) De Not. & + & \\
\hline Bacidia rubella (Hoffm.) A. Massal. & + & \\
\hline Bacidia subincompta (Nyl.) Arnold & & + \\
\hline Bacidina sulphurella (Samp.) M. Hauck \& V. Wirth & + & \\
\hline Biatora efflorescens (Hedl.) Räsänen & + & + \\
\hline Biatora globulosa (Flörke) Fr. & + & \\
\hline Bryoria implexa (Hoffm.) Brodo \& D. Hawksw. & + & + \\
\hline Bryoria sophiae (Motyka) Bystrek & & + \\
\hline Bryoria vrangiana (Gyeln.) Brodo \& D. Hawksw. & & + \\
\hline Calicium adspersum Pers. & + & + \\
\hline Calicium salicinum Pers. & + & \\
\hline Calicium viride Pers. & + & + \\
\hline Chaenotheca brachypoda (Ach.) Tibell & + & + \\
\hline Chaenotheca brunneola (Ach.) Müll. Arg. & + & \\
\hline Chaenotheca furfuracea (L.) Tibell & + & + \\
\hline
\end{tabular}




\begin{tabular}{|c|c|c|}
\hline Species & Primeval refuge & Regenerative refuge \\
\hline Chaenotheca trichialis (Ach.) Hellb. & & + \\
\hline Chrysothrix candelaris (L.) J.R. Laundon & + & + \\
\hline Chrysothrix flavovirens Tønsberg & + & \\
\hline Fellhanera bouteillei (Desm.) Vězda & & + \\
\hline Gyalecta flotovii Körb. & & + \\
\hline Hypogymnia farinacea Zopf & & + \\
\hline Lobaria pulmonaria (L.) Hoffm. & + & \\
\hline Micarea elachista (Körb.) Coppins \& R. Sant. & + & \\
\hline Micarea melaena (Nyl.) Hedl. & + & + \\
\hline Opegrapha vermicellifera (J. Kunze) J.R. Laundon & + & \\
\hline Opegrapha vulgata (Ach.) Ach. & + & \\
\hline Pertusaria flavida (DC.) J.R. Laundon & + & \\
\hline Pertusaria leioplaca DC. & + & + \\
\hline Pertusaria pertusa (L.) Tuck. & + & + \\
\hline Pseudoschismatomma rufescens (Pers.) Ertz \& Tehler & + & + \\
\hline Pyrenula nitida (Weigel) Ach. & + & + \\
\hline Pyrenula nitidella (Flörke ex Schaer.) Müll. Arg. & + & \\
\hline Ramalina baltica Lettau & + & \\
\hline Usnea fulvoreagens (Räsänen) Räsänen & & + \\
\hline Varicellaria hemisphaerica (Flörke) I. Schmitt \& Lumbsch & + & + \\
\hline
\end{tabular}

type and scale of human intervention, distribution and resources of valuable species), a dichotomic key was created that was used to classify them:

1. Indicator lichen species distinguishing the area as a refuge

a. already existed in it as a permanent element of the environment ........2

b. colonized it in an extraneous manner "from the outside"............3

2. The nature of the area and the distribution of species

a. typically small areas, fairly homogeneous, stable habitats, with little environmentally detrimental human pressure, species dispersed \pm in the whole area (if aggregated, then on short distances), a high number of potential habitats in all or majority of the area - primeval (natural) refuge b. usually large-surface areas, very heterogeneous, subject to human activity, species arranged clearly disjunctively throughout the area in aggregates (or as single localities), a limited number of potential habitats (often very distant), a noticeable spread of species around the centers of occurrence - regenerative (semi-natural) refuge

3. Etiology of refuge formation

a. Direct or indirect human pressure - colonized (anthropogenic) refuge

b. Absence or cessation of anthropogenic pressure incidental (spontaneous) refuge.

In view of the results of research carried out in the Krajeńskie Lakeland, three types of refuges were distinguished in this region: primeval, regenerative and colonized refuges. A possibility of existence of another type of refuge was indicated, which was defined as incidental. 


\subsection{Characteristics of refuges}

Primeval (natural) - in which significant species of lichens are present, lasting with the remains of ecosystems existing in the environmental space for a long time. The occurrence of endangered, rare species in them is a result of persistence of the remaining (often fragmentary) population, which was present in the area in the past. This is an area which "survived" the common changes introduced by man and "survived" among degraded and transformed ecosystems (Fig. 2). They represent fairly compact areas with a greater or lesser degree of naturalness with a minimal human activity - mostly aimed at sustaining them. This is undoubtedly the most valuable group of refuges. Areas with well-preserved biota (or at least its remnants) are a valuable reservoir of propagules, from where species can spread. Among the determined refuges in the Krajeńskie Lakeland, areas of nature reserves: Osiedle Kormoranów, Sosny, Buczyna, Dęby Krajeńskie, Borek, Zielona Góra were included in this category (Fig. 3). The status of nature reserve protects them from the negative effects of forest management leading to the destruction of trees, where valuable lichens are present. Such areas require mainly maintenance works, protecting the stability of lichen biota habitats.
Regenerative (semi-natural) - these are areas with the remnants of naturalness, where there is human intervention, but it is smaller, i.e., not as frequent and/or not as intensive, as in other areas. Biodiversity of such areas is a result of previous changes in the environment caused by, e.g., forest management (logging, thinning, removing fallen trees etc.), the consequence of which is the low diversity of habitats. Examples of such refuges are fragments of stands, in which impoverished (and usually fairly dispersed) biota of valuable lichens still persists (Fig. 4). Their occurrence in the particular area indicates the persistence of favorable combination of environmental factors. In such areas, the process of recolonization is visible, which with appropriate management will still occur there. Due to the possible potential and deficiency of other areas of a refuge nature, they must also be treated as a priority. Lichens associated with this type of refuges are highly endangered, because habitat restoration with an appropriate species composition of biota is very difficult and extended in time. In addition, rare species localities are often involuntarily damaged. As regards the Krajeńskie Lakeland, part of the "Torfowisko Messy" Landscape-Nature Protected Complex, "Uroczyska Złotowskie" Natura 2000 area and the "Struga Białośliwka" Natura 2000 were included into this type of refuges (Fig. 3).

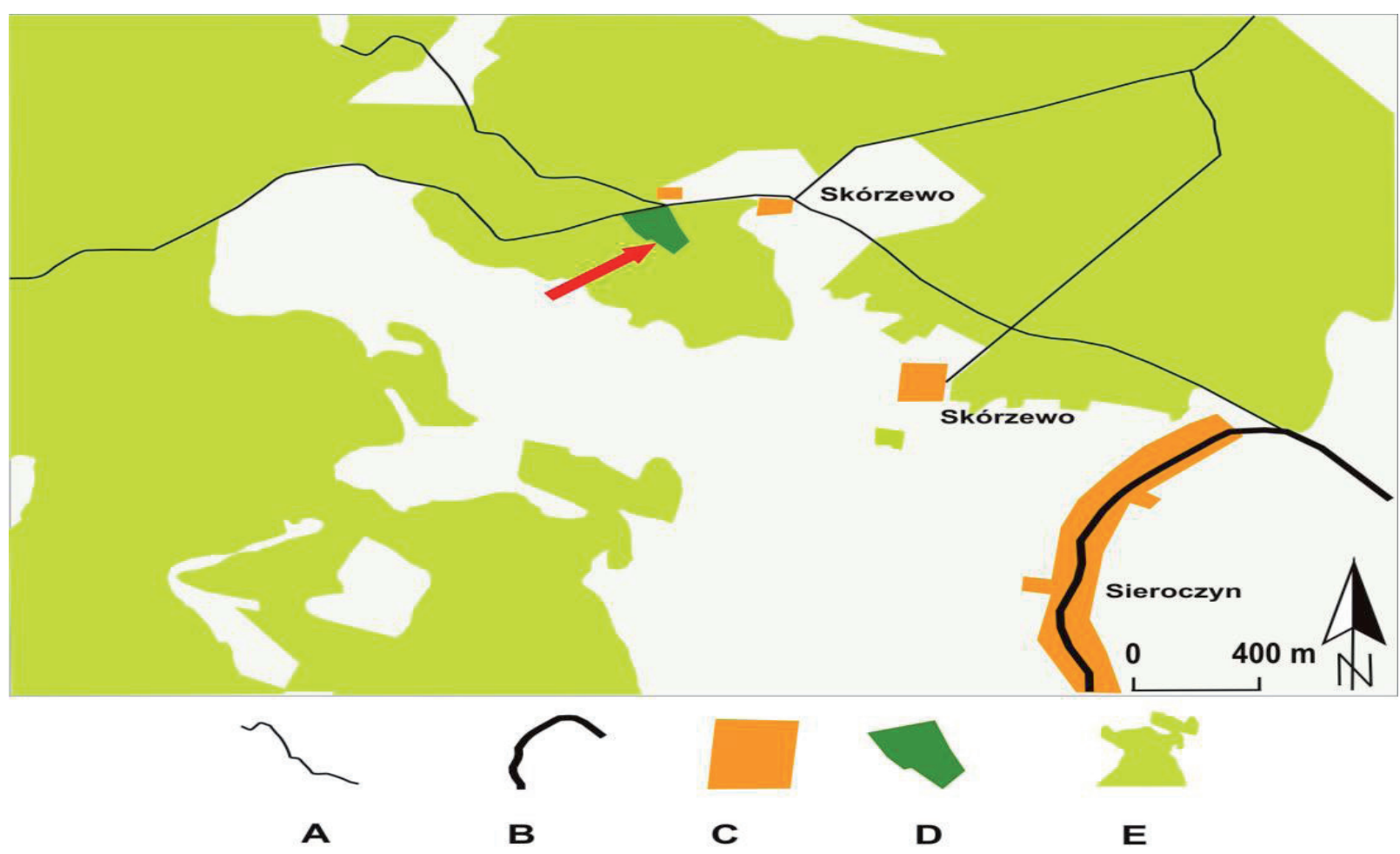

Figure 2. Location of the "Sosny" reserve, as an example of primeval refuge A - unpaved roads, B - roads, C - built-up areas, D reserve, E - commercial forests (Gruszka, 2014) 
Colonized (anthropogenic) - formed solely by human activities and entirely subject to his intervention (which is often a condition of their persistence). They are colonized by lichens extraneously from outside the refuge area. Examples of such refuges in the Krajeńskie Lakeland are some roadside tree alleys and valuable taxa associated with them that include: Anaptychia ciliaris, Ramalina spp., Pleurosticta acetabulum, Physconia perisidiosa, Melanelixia spp. Melanohalea spp.

In view of frequent logging of roadside trees, the role of alleys that have been preserved begins to significantly increase. Most valuable lichenologically sections of the al-

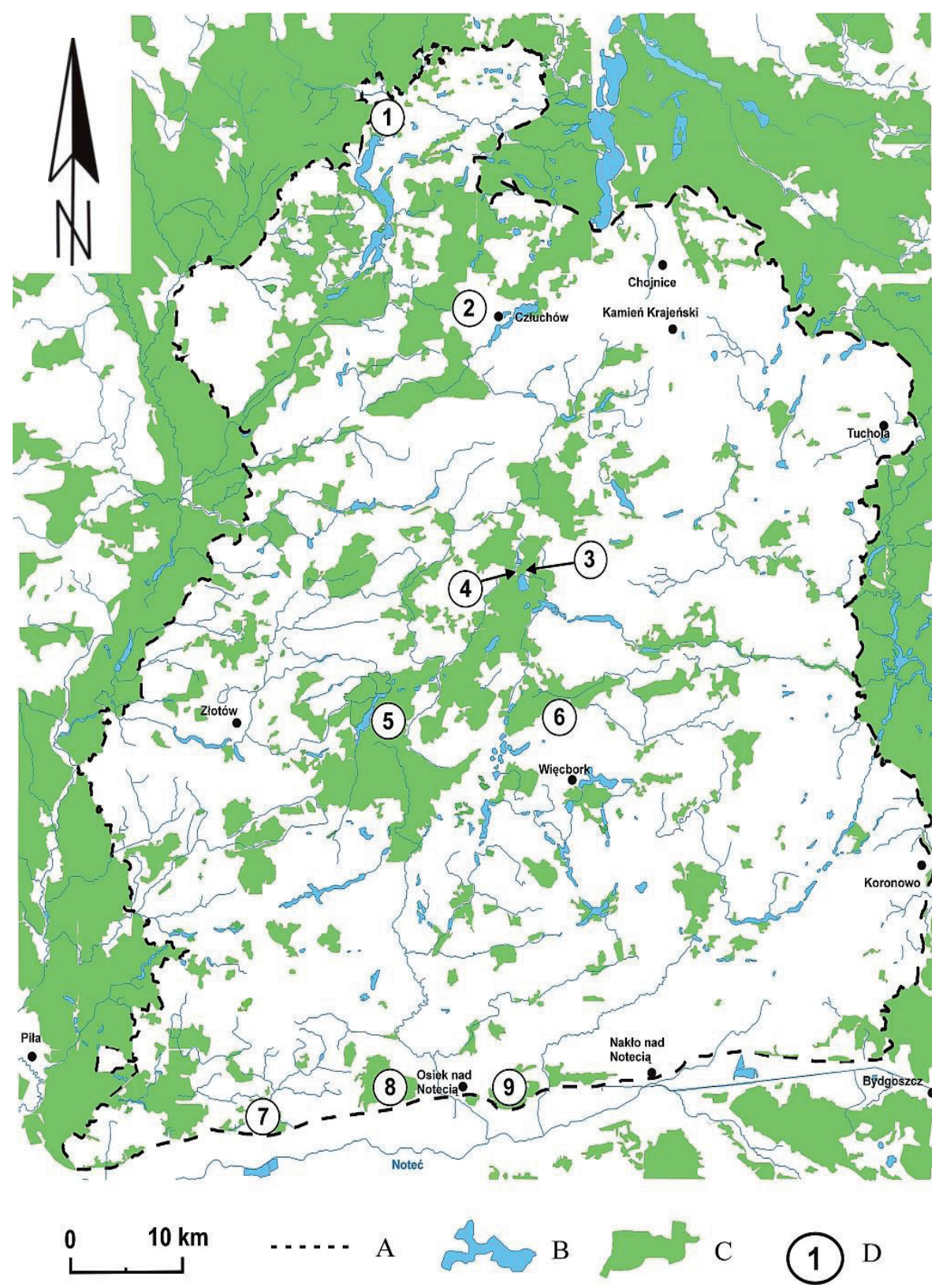

Figure 3. Distribution of primeval and regenerative lichen refuges in the Krajeńskie Lakeland (Gruszka, 2014). Explanations: A Krajeńskie Lakeland border, B - water bodies, C - forest areas, D - lichen refuge: 1 - "Osiedle Kormoranów" nature reserve; 2 - "Sosny" nature reserve; 3 - "Buczyna" nature reserve; 4 - "Dęby Krajeńskie" nature reserve; 5 - "Uroczyska Złotowskie" Nature 2000 area; 6 - "Torfowisko Messy" Landscape-Nature Protected Complex; 7 - "Struga Białośliwka" Nature 2000 area; 8 - "Zielona Góra" nature reserve ; 9 - "Borek" nature reserve 


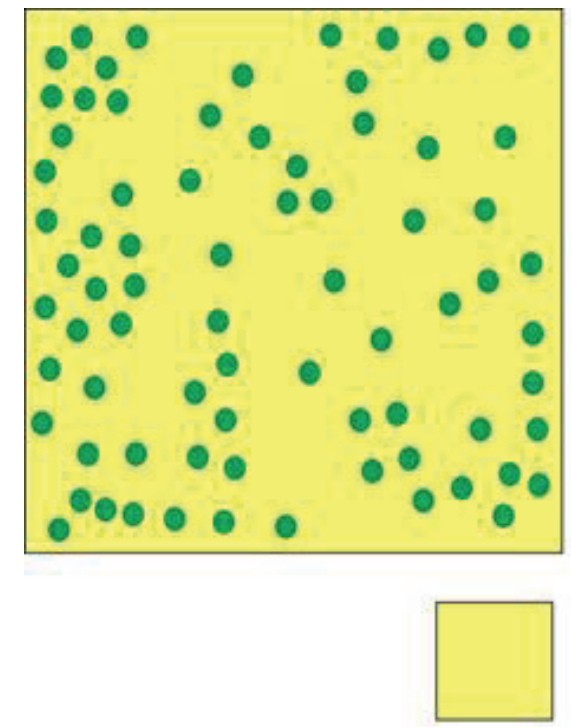

A
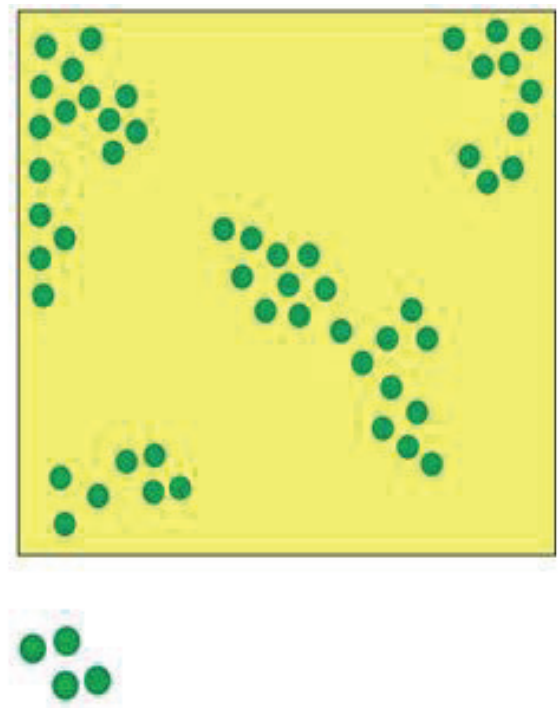

B

Figure 4. Schematic distribution of lichen indicators localities in the primeval (left) and regenerative (right) refuge A - refuge area, $\mathrm{B}$ - lichen indicators localities

leys are located, among others, between Prusionowo and Rozwory (near Debrzno), between Głubczyn and Krajenka, between Dąbrówa and Drożdzienica (near Sępólno Krajeńskie), between Więcbork and Jastrzębiec, between the villages of Szczytno and Lisewo (near Przechlewo). The only lichen refuge of this type subject to legal protection, as a natural monument is almost a two-kilometerlong alley (Fig. 5) between Powałki and Jarcewo in Tuchola Forest (Lipnicki, 2012). Previous attempts to protect other, most valuable lichenologically alleys or fragments thereof in the region of the Krajeńskie Lakeland were unfortunately not approved by the representatives of local authorities and failed, despite the submission of relevant applications and proposals (Gruszka, 2012).

Incidental (spontaneous) - as opposed to anthropogenic, the impetus to the formation of incidental refuge is not direct human activity, but its absence or cessation, which created suitable conditions for the colonization of the area by lichens. This group includes an area originally devoid of lichens, in which changes have occurred enabling their emergence de novo. It was assumed that spontaneously appearing wooded lands could be an example of such refuge.

However, lichenological studies in the Krajeńskie Lakeland did not demonstrate that mid-field patches of trees constitute lichen biota refuges. In fact, the whole core of biota was represented by a widespread, ubiquitous species resistant to human pressure (including Lecanora conizaeoides, Hypocenomyce scalaris, Hypogymnia physodes,
Parmelia sulcata). Therefore, no outstanding and distinctive lichenological qualities were found. In addition to poor species representation, lichens were observed only in marginal, better lit parts, where the light access was greater. High canopy shading and a very strong development of the understory layer prevented the development of epiphytic lichens in the internal parts of trees. Hence this type of refuge has not been found during the study.

\section{Discussion}

The reference to the results of other studies related to this issue is difficult, because the lichenological literature is scarce in terms of detailed studies on lichen refuges, as a stand-alone subject. The results of research carried out in the Krajeńskie Lakeland confirm that this is currently a matter of particular importance. For in the process of broadly understood anthropogenic changes and lichen protection proposals submitted for a long time (including Motyka, 1934; Szwejkowski \& Tobolewski, 1959; Lipnicki, 1988, 1991; Fałtynowicz, 1992), refuges have played and will play an increasingly important role in preserving biodiversity (Cieśliński \& Czyżewska, 2002; Cieśliński, 2009), or as a source of propagules, from which lichens will be able to spread (Doering \& Coxson, 2010). Białowieża Forest (Cieśliński \& Czyżewska, 2002; Kościelniak, 2008; Golubkov et al., 2012), Bieszczady (Kościelniak, 2009, 


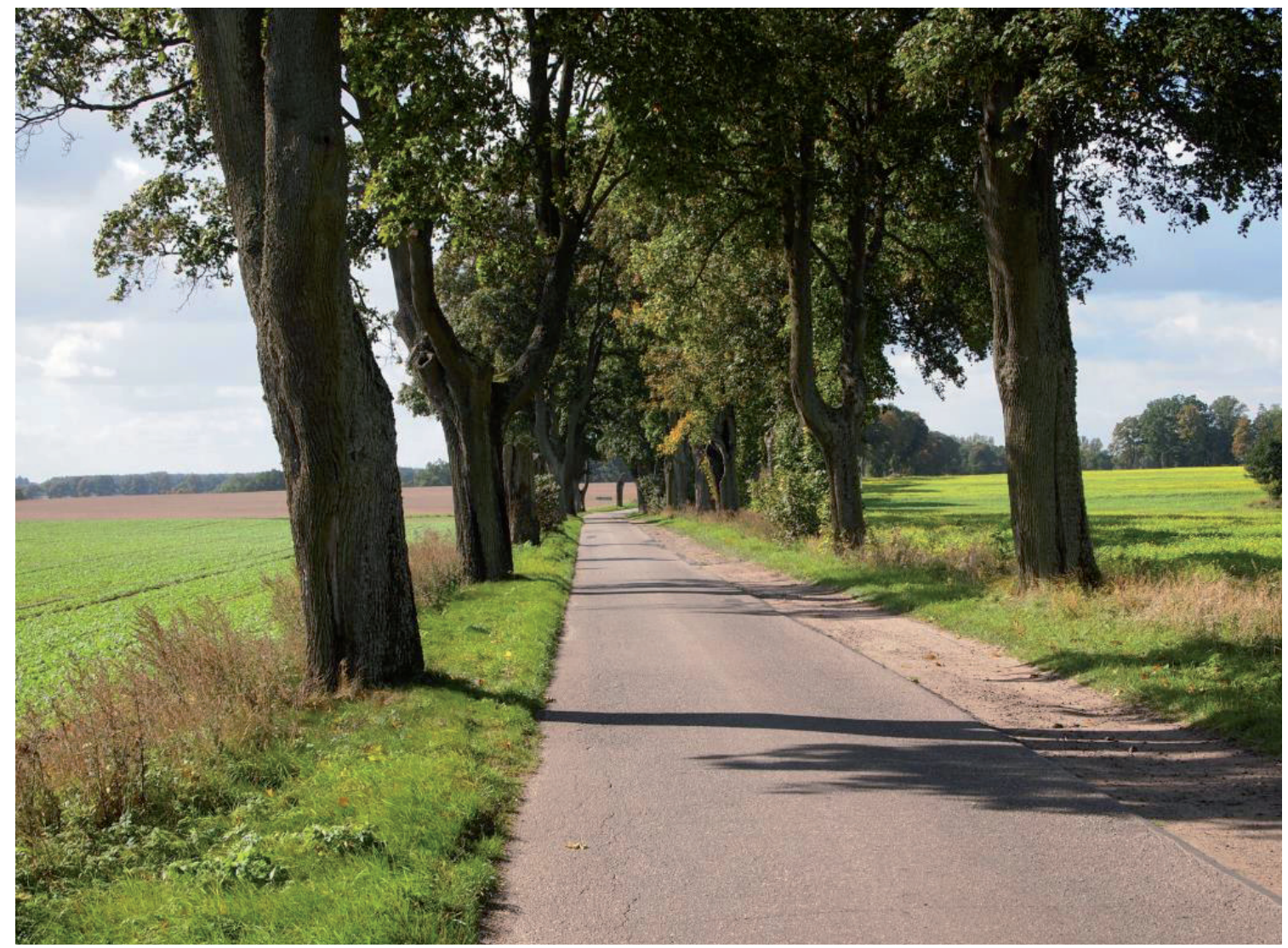

Figure 5. Roadside tree alley between the villages Powałki and Jarcewo as an example of anthropogenic refuge (Photo by Wojciech Gruszka)

and literature cited therein) and Tuchola Forest (Lipnicki, 2012) are among the most important national centers of lichen species diversity. Examples of centers at the regional level include the following reserves: Budzisk, Starożyn, Borki, Warmia Forest, Krutynia, Zagożdzon (Czyżewska at. al., 2002; Czyżewska \& Cieśliński, 2003).

In contrast to the provided definition (Mirek et al., 2005), it was assumed that lichen refuge does not necessarily have to be the area with semi-natural characteristics (at least), but even the object completely shaped by man, on which valuable taxa remain. The most important for the area is the protection of populations of rare species. Therefore, with respect to lichens, lower naturalness of such an object should not be a disqualifying factor.

However, the naturalness of ecosystems is a particularly important factor (Cieśliński \& Tobolewski, 1988; Cieśliński et al., 1996; Dettki \& Esseen, 1998; Lesica et al., 1991; Czyżewska \& Cieśliński, 2003; Kubiak \& Sucharzewska, 2012 after Kubiak, 2013), and should be taken into account as a parameter at the beginning of searching for lichen refuges. This is due to the fact that the process of renaturalization of isolated forest fragments on the post- agral land occurrs only whith the inflow of diaspores from the outside. First, the available habitats are occupied by species with wide tolerance. This regularity was observed in the case of vascular plants (Woziwoda, 2006), but it is also related to the spread of lichens, as none of the examined wooded lands contained typical forest species or species belonging to the relics of primeval forests. On the other hand, in the area of the Krajeńskie Lakeland, roadside tree alleys and their associated threatened taxa (Anaptychia ciliaris, Ramalina spp., Pleurosticta acetabulum, Physconia perisidiosa) are undoubtedly examples of refuges, which are not of natural origin (in this case, they are not the forests remnants). Some of these species are still relatively common, but due to numerous loggings and air pollution (Fałtynowicz, 1992), their degree of extinction danger increases. It should be noted that each species has a number threshold, below which a population is facing the threat of extinction from year to year (Wilson, 1999).

Considering the fact that the most important and most effective method is protection in situ (Cieśliński \& Czyżewska, 2002), and the fact that the refuge problem is discussed to a small extent in the lichenological litera- 
ture, there is a need for further research. These investigations should identify new refuges of lichens and include stability analysis and transformation of lichen biota in areas already designated as refuges.

The author realizes that theses and proposals contained in this publication are novel and not exhaustive. The author counts for their constructive assessment and verification, and hopes for a substantial discussion, which will result in the formulation of new proposals complementing the subject.

\section{Conclusions}

The following conclusions can be drawn from the results of lichen biota analysis and the discussion presented in this paper:

1. In the area of refugee, it is necessary to examine the indicated area in order to identify the most valuable species, which are indicators of the refugees.

2. The most suitable areas for refugee typing are forest areas that are distinguished by the presence of natural-like fragments with old trees.

3. Each refuge should be examined individually as it relates to its size, character, human influence, the degree of isolation, regeneration capacity.

4. Due to the fact that the problem of the refugee is to a lesser extent taken into account in lichenological literature, further research seems to be justified in this regard.

\section{Acknowledgements}

The author would like to thank Ass. Prof. Ludwik Lipnicki for critical reading of the first version of this publication and anonymous Reviewer for constructive comments and suggestions.

\section{References}

Bielczyk U., 2012, Lichens of zinc-lead post-mining areas in the Olkusz region - state of preservation, threats and needs for protection, [in:] Lichens Protection - Protected Lichen Species, L. Lipnicki (ed.) Sonar Literacki, Gorzów Wielkopolski: 119-128.

Cieśliński S., 1999, Ostoja bioróżnorodności flory porostów w uroczysku leśnym „Żyznów” koło Klimontowa [Biodiversity of lichen flora in forest range ‘Żyznów' near Klimontów], [in:] Bioróżnorodność obszarów stykowych Kotliny Sandomierskiej, Wyżyny Kielecko-Sandomierskiej oraz Wyżyny Lubelskiej, materiały z sympozjum, Sandomierz 23 września 1999, [Biodiversity of adjacent areas of Sandomierz Valley, Kielce-Sandomierz Uplands and Lublin Upland, Symposium materials, Sandomierz 23 September 1999], T. Puszkar (ed.), Towarzystwo Naukowe Sandomierskie [Scientific Society of Sandomierz], Sandomierz: 10-22.

Cieśliński S., 2000, Białe Ługi Reserve: a refuge of the forest lichen flora of the Góry Świętokrzyskie Mountains. Fragmenta Floristica et Geobotanica 45(1-2): 485-492.

Cieśliński S., 2003, Atlas rozmieszczenia porostów (Lichenes) w Polsce północno-wschodniej [Distribution atlas of lichens (Lichenes) in north-eastern Poland], Phytocoenosis 15(N.S.), Suppl. Cartographiae Geobotanicae 15: 1-430.

Cieśliński S., 2006, The Krzemionki Opatowskie Reserve: a refuge of lichen in Central Poland, Nature Conservation 62: 13-25.

Cieśliński S., 2009, Znaczenie ochrony rezerwatowej dla zachowania bioty porostów (Ascomycota lichenisati) w Puszczy Kozienickiej [The role of nature reserves in conservation of the lichen biota (Ascomycota Lichenisati) in Kozienicka Primeval Forest], Parki Narodowe i Rezerwaty Przyrody 28(1): 3-35.

Cieśliński S., Czyżewska K. \& Fabiszewski J., 2006, Red list of the lichens in Poland, [in:] Red list of plants and fungi in Poland, Z. Mirek, K. Zarzycki, W. Wojewoda, Z. Szeląg (eds.), W. Szafer Institute of Botany, Polish Academy of Sciences, Kraków: 71-89.

Cieśliński S. \& Czyżewska K., 2002, Porosty Puszczy Białowieskiej na tle innych kompleksów leśnych w Polsce Północno-Wschodniej [Lichens of Białowieża primeval forest in comparison with other forest complexes in north-eastern Poland], Kosmos 51(4): 443 451.

Cieśliński S., Czyżewska K., Faliński J.B., Klama H., Mułenko W. \& Żarnowiec J., 1996, Relikty lasu puszczańskiego. Zjawiska reliktowe [Relicts of the primeval (virgin) forest: relict phenomena], [in:] Białowieski Park Narodowy (1921-1996) w badaniach geobotanicznych [Białowieża National Park in geobotanical research], J.B. Faliński (ed.), Phytocoenosis 4: 47-64.

Cieśliński S. \& Tobolewski Z., 1988, Porosty (Lichenes) Puszczy Białowieskiej i jej zachodniego przedpola [Lichens (Lichenes) of the Białowieża Forest and its western foreland], Phytocoenosis, 1 (N.S.), Supplementum Cartographiace Geobotanicae, 1: 3-216.

Czarnota P., 2012, Lichen protection needs natural forest disturbances - examples from some Polish Western Carpathian national parks, [in:] Lichens Protection Protected Lichen Species, L. Lipnicki (ed.) Sonar Literacki, Gorzów Wielkopolski: 53-66. 
Czyżewska K. \& Cieśliński S., 2003, Porosty - wskaźniki niżowych lasów puszczańskich w Polsce [Lichens - indicators of lowland old-growth forests in Poland], [in:] Zagrożenie porostów w Polsce [Threat to lichens in Poland], K. Czyżewska (ed.), Monographiae Botanicae, 91: 223-239.

Czyżewska K., Cieśliński S., Motiejūnaitė J. \& Kolanko K., 2002, The Budzisk nature reserve as a biocentre of lichen diversity in the Knyszyńska Large Forest (NE Poland), Acta Mycologica 37 (1/2): 77-92.

Dettki H. \& Esseen P.-A., 1998, Epiphytic macrolichens in managed and natural forest landscapes: a comparison at two spatial scales, Ecography 21: 613-624.

Doering M., Coxson D., 2010, Riparian alder ecosystems as epiphytic lichen refugia in sub-boreal spruce forests of British Columbia, Botany 88: 144-157.

Fałtynowicz W., 1992, Porosty Pomorza Zachodniego. Studium ekologiczno-geograficzne [The lichens of Western Pomerana (NW Poland). An ecogeographical study], Polish Bot. Stud. 4: 1-182.

Golubkov V., Bohdan A. \& Popławska M., 2012, Nowe, rzadkie i interesujące gatunki porostów Białowieskiego Parku Narodowego [New, rare and interesting lichens of the Bialowieza National Park], Parki Narodowe i Rezerwaty Przyrody 30(2): 15-26.

Gruszka W., 2010, Porosty rezerwatu „Osiedle Kormoranów" na Pojezierzu Krajeńskim (północno-zachodnia Polska) [Lichens of the "Osiedle Kormoranów" reserve in Krajeńskie Lake District (north-western Poland)], Parki Narodowe i Rezerwaty Przyrody 29(2): 41-49.

Gruszka W., 2011, Biota porostów rezerwatu przyrody „Diabli Skok” koło Szwecji (północno-zachodnia Polska) [The lichen flora of the "Diabli Skok" reserve near Szwecja (north-western Poland)], Chrońmy Przyrodę Ojczystą 67(1): 55-61.

Gruszka W., 2012, The protected and threatened lichens of the roadside trees in the Krajeńskie Lakeland, [in:] Lichens Protection - Protected Lichen Species, L. Lipnicki (ed.) Sonar Literacki, Gorzów Wielkopolski: $277-286$.

Gruszka W., 2014, Refugia porostów epifitycznych na Pojezierzu Krajeńskim [Epiphytic lichens refuge in the Krajeńskie Lakeland], (unpublished doctoral dissertation). Nicolaus Copernicus University, Toruń.

Hachułka M., 2012, Protected and threatened lichens in the Wzniesienia Łódzkie Landscape Park (Central Poland), [in:] Lichens Protection - Protected Lichen Species, L. Lipnicki (ed.) Sonar Literacki, Gorzów Wielkopolski: 243-252.

Index Fungorum, 2017, http:/www.indexfungorum.org/ names/names.asp [Accessed 26.09.2014].

Kapek M., 2014, Opuszczone wsie w Bieszczadach jako ostoje zagrożonych i chronionych gatunków porostów $\mathrm{w}$ Polsce [Vanished villages in the Bieszczady Mts as refuges of threatened and protected lichens in Poland], Fragm. Florist. Geobot. Polon. 21(1): 147-164.

Kolanko K., 2009, Porosty rezerwatu przyrody „Starodrzew Szyndzielski" w Parku Krajobrazowym Puszczy Knyszyńskiej (północno-wschodnia Polska) [Lichens of the nature reserve of 'Starodrzew Szyndzielski' in Knyszyńska Forest Landscape Park (north-eastern Poland)], Parki Narodowe i Rezerwaty Przyrody 28(2): 29-43.

Kondracki J., 2002, Geografia regionalna Polski [The regional geography of Poland], Państwowe Wydawnictwo Naukowe, Warszawa.

Kopaliński W., 2007, Słownik wyrazów obcych i zwrotów obcojęzycznych [Dictionary of foreign word and phrases], Wyd. Rytm, Warszawa.

Kościelniak R., 2005, Ostoja porostów w dolinie potoku Smorż koło Ustrzyk Dolnych [Lichen refuge in the Smorż stream valley near Ustrzyki Dolne], Roczniki Bieszczadzkie 13: 249-259.

Kościelniak R., 2008, Znaczenie lasów o charakterze pierwotnym i naturalnym dla zachowania różnorodności gatunkowej porostów w Bieszczadach [The importance of primeval and natural forests for preservation of species diversity of lichens in the Bieszczady Mts.], Roczniki Bieszczadzkie 16: 67-76.

Kościelniak R., 2009, The Bieszczady Mts as a Refuge for Protected and Threatened Lichens in Poland, [in:] Rare, relict and endangered plant species in Poland, Z. Mirek, A. Nikel (eds), Szafer Institute of Botany, Polish Academy of Sciences, Kraków: 269-275.

Kościelniak R., 2012, Red list of threatened lichens in the Bieszczady National Park, [in:] Lichens Protection Protected Lichen Species, L. Lipnicki (ed.), Sonar Literacki, Gorzów Wielkopolski: 301-311.

Kossowska M., 2002, Ostoja rzadkich porostów epifitycznych na jodłach w Wąwozie Szklarki (Karkonoski Park Narodowy) [Refuge of rare epiphytic lichens on firs in Szklarka Gully (Karkonosze National Park), Przyroda Sudetów Zachodnich [Nature of the Western Sudetes] 5: 85-92.

Kubiak D., 2011, Stan zachowania bioty porostów w rezerwatach „Dęby Napiwodzkie” i „Koniuszanka II” na Pojezierzu Olsztyńskim [State of preservation of the lichen biota in the Dęby Napiwodzkie and Koniuszanka II nature reserve in the Olsztyn Lakeland], Parki Narodowe i Rezerwaty Przyrody 30(3-4): 27-39.

Kubiak D., 2013, Znaczenie starodrzewu dla zachowania różnorodności porostów w lasach na przykładzie pozostałości Puszczy Mazowieckiej [The significance of old-growth forests in maintaining lichen diversity an example from the remnants of the Mazovian Forest], Leśne Prace Badawcze 74(3): 245-255.

Kubiak D. \& Kukwa M., 2011, Chromatografia cienkowarstwowa (TLC) w lichenologii [Thin Layer Chromato- 
graphy in lichenology], [in:] Mikologia laboratoryjna. Przygotowanie materiału badawczego i diagnostyka [Laboratory Mycology. Preparation of research material and diagnostics], M. Dynowska, E. Ejdys (eds), Wyd. UWM, Olsztyn: 176-183.

Kubiak D. \& Sucharzewska E., 2012, Porosty - wskaźniki niżowych lasów puszczańskich w zespołach leśnych rezerwatu „Las Warmiński” (Nadleśnictwo Nowe Ramuki) [Lichens - indicators of lowland old-growth forests in forest communities of the 'Las Warmiński' nature reserve (Nowe Ramuki Forest District)], Sylwan 156(8): 627-636.

Kukwa M. \& Jabłońska A., 2006, Uzupełnienie do bioty porostowej rezerwatu „Cisy w Czarnem” na Pomorzu Gdańskim [Addition to the lichen biota of 'Cisy w Czarnem' nature reserve in Gdańsk Pomerania], Acta Botanica Cassubica 6: 173-177.

Lesica P., McCune B., Cooper S.V. \& Hong W.S., 1991, Differences in lichen and bryophyte communities between old-growth and managed second growth forests in Swan Valley, Montana, Canadian Journal of Botany 69: $1745-1755$

Lipnicki L., 1988, Wymagające ochrony stanowiska porostów na terenie Borów Tucholskich [High conservation value sites of lichens in Tuchola Forest], [in:] Ochrona przyrody Borów Tucholskich. I Konferencja Naukowa, Toruń - Bydgoszcz [Nature protection of Tuchola Forest. The First Scientific Conference, Torun Bydgoszcz], Zakład Taksonomii i Geografii Roślin, UMK Toruń, Międzywydziałowy Zakład Ochrony Środowiska ATR Bydgoszcz, Bydgoskie Towarzystwo Ekologiczne, Bydgoszcz: 154-166.

Lipnicki L., 1991, Uwagi o potrzebie i możliwościach praktycznej ochrony porostów [Notes about the need and possibilities of practical protection of lichens], [in:] V Zjazd Lichenologów Polskich. Porosty (Lichenes) Pszczewskiego Parku Krajobrazowego [The 5th Congress of Polish Lichenologists. Lichens of Pszczew Landscape Park], L. Lipnicki (ed.), Instytut Badań i Ekspertyz Naukowych, Gorzów Wlkp.: 103-106.

Lipnicki L., 2012, Porosty w Parku Narodowym „Bory Tucholskie" [Lichens of Tuchola Forest National Park], [in:] Świat roślin i grzybów Parku Narodowego „Bory Tucholskie" [Plants and mushrooms of Tuchola Forest National Park, J. Matuszkiewicz (ed.), Park Narodowy „Bory Tucholskie”, Charzykowy: 316-357.

Mirek Z., Nikel A., Paul W. \& Wilk Ł. (ed.), 2005, Ostoje roślinne w Polsce [Important Plant Areas in Poland], Wyd. IB PAN, Kraków.

Motyka J., 1934, W sprawie ochrony porostów [On the protection of lichens], Ochrona Przyrody 14: 50-56.
Orange A., James P.W. \& White F.J., 2001, Microchemical methods for the identification of Lichens, British Lichen Society, London.

Prognoza oddziaływania na środowisko planu urządzenia lasu Nadleśnictwa Lutówko, 2005, [Forecast of the environmental impact of the forest management plan for Lutówko Forest Division], Lutówko, mscr.

Prognoza oddziaływania na środowisko planu urządzenia lasu Nadleśnictwa Runowo [Forecast of the environmental impact of the forest management plan for Runowo Forest Division], 2005, Runowo, mscr.

Rozporządzenie Ministra Środowiska z dnia 16 października 2014 r. w sprawie ochrony gatunkowej grzybów, Dz. U. RP 2014, Kanc. Prez. Rady Min., poz. 1408 [Regulation of the Minister of the Environment of 16 October 2014 on the protection of fungi species, Journal of Laws RP 2014, item 1408, Chancellery of the Prime Minister, Warszawa], 2014.

Szwejkowski J. \& Tobolewski Z., 1959, Zagadnienia ochrony roślin zarodnikowych [The protection of the spore-plants.], Ochrona Przyrody, 26: 56-64.

Trampler T., Kliczkowska A., Dmyterko E. \& Sierpińska A., 1990, Regionalizacja przyrodniczo-leśna na podstawach ekologiczno-fizjograficznych [Regionalization of the Naturel Forest according to the Ecological and Physiographical Conditions], PWRiL, Warszawa.

Umiński J., 1991, Pojezierze Krajeńskie [Krajeńskie Lakeland], Wyd. PTTK „Kraj”, Warszawa.

Waldon B. \& Ratyńska H., 2008, Drobne zbiorniki wodne Pojezierza Krajeńskiego jako siedliska rzadkich i zagrożonych gatunków roślin [Small water bodies in the Krajeńskie Lakeland and diversity of vegetation refuges], [in:] Krajobraz i bioróżnorodność [Landscape and biodiversity], S. Kaczmarek (ed.), Wyd. Uniw. Kazimierza Wielkiego, Bydgoszcz.

Wilson O., 1999, Różnorodność życia [The Diversity of Life], Państwowy Instytut Wydawniczy, Warszawa.

Wójciak H. \& Urban D., 2012, Small mid-forest and midfield peatbogs as a refuge of rare and protected lichens species, [in:] Lichens Protection - Protected Lichen Species, L. Lipnicki (ed.), Sonar Literacki, Gorzów Wielkopolski: 133-141.

Woziwoda B., 2006, Różnorodność florystyczna różnowiekowych lasów, izolowanych w krajobrazie rolniczym Polski Środkowej a problem zachowania i ochrony rodzimych gatunków leśnych [Floral diversity of multiage forests isolated in agricultural landscape in Central Poland versus problem of maintain and protection of native forest species], [in:] Aktywne metody ochrony przyrody $\mathrm{w}$ zrównoważonym leśnictwie [Active methods of nature conservation in sustainable forestry], D. Anderwald (ed.), Studia i Materiały Centrum Edukacji Przyrodniczo-Leśnej, R. 8, 1(11): 103-109. 